\title{
Understanding the Justice in Agatha Christie's Murder on The Orient Express
}

\author{
Lucky Aditya \\ English Department, Faculty of Languages and Literature, Petra Christian University, Siwalankerto 121- \\ 131, Surabaya 60236, INDONESIA \\ Email: zpider17@gmail.com
}

\begin{abstract}
This thesis deals with the understanding of justice in the novel. I use theory of retributive justice and two supporting theories about morality and code of conducts of private investigators. In this analysis, I analyze two characters who have strong reasons in helping me understand the justice. I analyze Hercule Poirot because he is the main character and also symbolizes justice due to his moral choice in the story. Next, I analyze Linda Arden because she is the mastermind and has the strong emotional scar to bring out her point of view of justice. The conclusion that can be found in this analysis is that justice in retribution includes an action that precedes the legal procedure. It can justify some action outside the legal written law.
\end{abstract}

Key words: Justice, morality, code, legality, procedure, criminal

\section{INTRODUCTION}

I see that literature has evolved for a long time that it gives both education and entertainment for its readers. Through some literature books that I have read, I learn a lot of humanity knowledge and abstract ideas. Literature also has its genres that make it unique among one another. One of the most famous genres in literary is mystery fiction. This one particular genre has given much in the development of human critical thinking, and in entertainment. According to Windhelm (2001), Mystery fiction is a genre of fiction which usually involves a mysterious case of death or crime to be solved. Most of mystery fiction start with a closed circle of suspects with each of their own credible motive and reasonable chances to commit the crime. Most of the times, the central character of mystery fiction will be a detective who as the story progresses will solve the mystery by logical deduction from facts presented to the reader. (p. 142).

The repeating and primary formula for this genre thus becomes: a murder has happened, the detective takes the case and investigates the case with his logical and strong deductive skills, and finally, the detective reveals the murderer and the plot twist of how the murder happens. For me, this becomes the main expectation of what detective novel should be every time I read mystery fiction due to its repeating formula of most of this genre. In my opinion, this primary formula of mystery fiction makes this genre become very unique compared to other fiction genres because in this genre, readers get to know the point of view of a murderer in doing a villainous act or knowing the process of logical deduction of a detective in solving a case.

Agatha Christie is one of the most known writers during the golden age of modern mystery fiction. Agatha Mary Clarissa Christie, Lady Mallowan, DBE, also known as the Queen of Crime, was born in Miller, 15 September 1890 and died on 12 January 1976. She was an English writer, and is known for her 66 detective novels and 14 short stories collections (Agatha Christie Bibliography, 2014). Christie also wrote the world's longest running play in a murder mystery, The Mousetrap. She received the DBE (Dame Commander of the Order of the British Empire) title in 1971 because of her contribution to the literature world. Her novels were listed 
in Guiness World Records as the best-selling novel of all time. This thesis analyzes her mostknown Poirot's adventure, Murder on the Orient Express. It had been adapted into a movie adaptation two times: the first one in the 1934 and the second one in 2017. Murder on the Orient Express also received a lot of good critics and review; both from real world magazines and online reviews. I choose to analyze one of her works because the author is very well-known and her works have been read by most people even up until now. I chose the novel, Murder on The Orient Express because the way the author brings the murder case and the solution of the problem is very different compared to the usual formula of mystery fiction (A murder has happened, the detective solves the cases, the detective reveals the murderer and the secrets of the murder). As a comparison is one of her works, The Murder of Roger Ackroyd, shows that the murder is done by one murderer. The usual ending of mystery novel resolves around a criminal or criminals who get caught and justice is served under the power of law. However, at the end of Murder on The Orient Express, it is revealed that the murderers are the twelve passengers of the first class car, and due to the revelation of the truth and the passengers past, the detective decided to let them go. This is a unique plot twist because most mystery fictions reveal only one or two murderers and the detective takes them to court. In the end, the detective decides not to turn the murderers to legal force. Thus, leaving me wondering whether justice was served or not in the end.

I am using the concept of retributive justice and the supporting theory of morality. The idea of retributive justice has existed from ancient Rome civilization. The term of Lex Talionis (an eye for an eye) becomes the first foundation of the retributive justice. The development of retributive view then reformed in a better understanding by Kant, on his book Science of Right (1790). The idea of retributive justice has played a dominant role in theorizing about punishment over the past few decades, the idea features on the concept of desert and proportionality, the normative status of suffering and the justification of retribution. This means, the consideration of what can be considered as justice in bringing retribution talks in a lot of aspects.

Retributive justice is a theory of justice that believes that the best response to a crime is a punishment proportional to the offense, inflicted because the offender deserves the punishment. According to Alec (2011), there are three principles of this justice:

(1) that those who commit certain kinds of wrongful acts, paradigmatically serious crimes, morally deserve to suffer a proportionate punishment; (2) that it is intrinsically morally goodgood without reference to any other goods that might arise - if some legitimate punisher gives them the punishment they deserve; and (3) that it is morally impermissible intentionally to punish the innocent or to inflict disproportionately large punishments on wrongdoers (para. 1).

This means this theory of justice mostly based itself on giving a deterrent effect to offenders by punishing them accordingly and to pay the damage done to the victims mentally and physically. In extreme cases, it could lead to killing the offender to prevent further offense as the last solution for the offense. I see the appeal of this theory rests on the direct intuitive support, in part on the claim that it is a better punishment compared to the other alternatives, and in part on arguments tied to deeper moral principles. By giving a proportionate punishment according to the offense done, the victim and the family can have a relief from some of the mental burden done by the scars done by the offender. 
Morality also plays its role in understanding justice. I need morality because one of the supporting component of justice is the standing of morality. The definition of morality has its two version: from descriptive definition and normative definition. According to Gert (2017), the term "morality" can be used either descriptively to refer to certain codes of conduct put forward by a society or a group (such as a religion), or accepted by an individual for her own behavior, or normatively to refer to a code of conduct that, given specified conditions, would be put forward by all rational persons. (para. 2)

In this context, the definition of morality itself does not have its absolute meaning as both definitions have their own contradicting point. However, in analyzing the point of view of Hercule Poirot and Linda Arden, and their actions, I use this definition of morality to support the point of view of both characters. For that, I need to dive more deeply to both definitions of morality.

If morality is being used as a code of conduct which is endorsed by groups which include a society even if it is different from etiquette, law, and religion then morality is being depicted in its descriptive form. Furthermore, according to Gert (2017), "It is also being used in the descriptive sense when it refers to important attitudes of individuals". In this definition, people will refer their code of operation or the way they believe what should they do as the basis of their morality. The aim of this descriptive definition is to refer on how the people believe how they should act in a certain morality practice. In simpler words, I see that morality is seen on its descriptive form as a personal code of conduct that does not force the practice towards other people.

Normative definition put itself more into a collective thoughts of moral belief. "Those who use "morality" normatively hold that morality is (or would be) the code that meets the following condition: all rational persons, under certain specified conditions, would endorse it" (Gert, 2017). Putting it into a more specific way, the concept of morality is an idea which can be generally accepted by everyone. In this way, it is how society deem something as moral and immoral. Through normative definition, morality can be seen as a natural law that would be endorsed by everyone else I apply this theory in analyzing Linda Arden's act of retribution and her action in killing Cassetti as an action that will be endorsed by the society.

I include the code of private detective to know the legality and the clear line of Poirot's responsibility. The code of conducts is that private investigators should accept responsibility for their actions and diligently carry out their roles in ways which ensure that they verify the credentials of clients to ensure that they have lawful and moral reasons to request an investigation, agree in advance with clients the objectives of the service and the fees, terms and conditions which will apply, act with honesty, integrity and must not compromise their position, respect and protect clients' and others' privacy and lawful confidentiality, including using appropriate and proportionate investigative and surveillance techniques, conduct all investigations within the bounds of legality, morality and professional ethics, accept only those commissions which they consider themselves qualified to carry out, promote through their general demeanor and in dealing with clients, the general public, colleagues and the authorities, the professionalism and integrity of the private investigation community, are to act with selfcontrol and tolerance, treating everyone with whom they come into contact, during the course of their activities, with respect, fairness and courtesy, act with fairness and impartiality. They will not discriminate unlawfully on the grounds of sex, race, color, language, religion or belief, political or other opinion, national or social origin, association with a national minority, disability, age, sexual orientation, property, birth or other status, challenge and when appropriate take action or report breaches of this code and the improper conduct of colleagues. (Regan, 2019) 
I use these ten codes in supporting my analysis of Poirot's legality and his method in bringing justice in the story.

\begin{abstract}
ANALYSIS
First, I analyze the main character, Hercule Poirot as he himself holds the role as the procedural role in the story. Through him, I found that the course of decisions he makes in the story is matching with the retributive justice theory or it is against it. In addition, I apply my code of conducts to show that the investigation he conducts is according to how private investigators should act or he violates some of the code to defend the justice through his point of view. First, I analyze his moral standing in a descriptive manner to support his point of view in dealing with the murder and how he considers Cassetti killing as just. In the second sub-heading, I analyze Linda Arden's point of view in retributive justice and her action in killing Cassetti as an act of delivering justice. Furthermore, I analyze her action alongside with eleven passengers in killing Cassetti as a moral action based on normative definition.
\end{abstract}

\title{
Retributive Justice and Morality in Poirot's point of view
}

The most famous character in Christie's stories and known for his short body and his unique moustache is Hercule Poirot. He embodies the mind of a judge and the power of law morality. His rational thinking and his critical deduction in solving his cases have made him as the greatest Yugoslav detective. His close friend, M.Bouc even pleaded him in taking the murder case.

Interview the passengers on the train, view the body, examine what clues there are, and thenwell, I have faith in you! I am assured that it is no idle boast of yours. Lie back and think-use (as I have heard you say so often) the little grey cells of the mind-and you will know!” (p.48)

M.Bouc's compliment and his trust towards Poirot shows how experienced and skillful he is in doing his task. His method of investigation shows that Poirot is an orderly man and quite critical in analyzing people. These traits show how he is very able in doing his investigation method and finding the justice in his critical point of view.

His point of view in understanding justice comes from his moral and intellectual knowledge. Due to this background, he always solves cases in brilliant ways. His critical analysis also helps in getting to know the others' point of view regarding the murder and their circumstances.

With this characteristics, Poirot is appropriate to have been called as a detective and a symbol of judge. His natural standing during investigating the case also supports how he fulfills his code of conducts.

\section{Descriptive Morality}

Poirot with his strong and logical analysis skill stands strong in the point of morality because justice stands not only from the written human law only. One of the examples of his strong side in morality is when he refuses Cassetti's offerings (p. 30-31). His action in refusing the case shows the neutrality of justice and how money cannot affect his standing on conducting his service.

In my opinion, his action in refusing Ratchett's offer shows that his morality stands on the descriptive definition. This is because he sees the killing of Cassetti as a way to deliver justice that the legal justice has failed to do. Thus, in his view, the killing of Cassetti is not a mistake. 
Furthermore, in the beginning he has no interest in protecting Ratchett. Poirot stated on the first time he sees Ratchett at the Totkalian Hotel that he has an unpleasant impression, and it is important to note that Poirot has a very precise analysis on people. Experienced in his field, Poirot knew the characteristics of specific people, in this opportunity, a criminal. His critical and strong analysis of Ratchett showed how true he is to his code and in knowing that Ratchett is not a good person at heart.

His action in proposing the solution of letting go the twelve passengers shows that his beliefs of the morality is based on the descriptive definition of morality. Through Poirot's choices in giving the solution outside the written law, he actually also proposes an idea that killing a criminal is justified if the court law has already violated from the beginning.

Through Poirot's descriptive morality, he sees justice as the act of being fair and reasonable. He sees through the truth of why the passengers killed Cassetti and let his friends decide the solution as the final choice of the passengers' fate and let the twelve passengers bring justice to the criminal.

\section{Retributive Justice and Code of Conducts}

This point talks about retributive justice through Poirot's point of view supported by his legal procedure and through the code of conducts of investigators. I analyze Poirot's actions in investigating the suspects and shows his understanding of the retribution through his interrogation. Although morality stands strong in defining justice, legal law still plays its important role in resolving the issue. In this case, Poirot acts as the legal force that brings justice to the table. His attitude of investigating the suspects also shows his understanding of the justice.

I see that his point of view of retributive justice comes in an objective approach; meaning that he holds strongly on his goal and does not tolerate on any circumstance that happens on the case. He does not see the murder case in a biased view. In doing the investigation, I also found that Poirot works with a great neutrality in unfolding the mysteries Poirot during his interactions with the twelve suspects is neutral and is not swayed away by emotions.

"So you pronounce one person at least innocent of the crime," said M. Bouc jovially.

Poirot cast on him a look of reproach.

"Me, I suspect everybody till the last minute," he said. (p.58)

In my opinion, this shows how strong he was to his objective and how he does not see everyone is innocent until he finds out the truth of the suspicion. Through this statement, I see that he only uses emotion slightly to calm his suspects and makes them cooperate in finding out the truth.

In this point, Poirot also fulfills most of code of conducts of private investigators. His skilled knowledge and his wit in unraveling the murder mysteries show that his procedure is legal and based on the 10 codes. One of the example is acting with self-control and tolerance, treating everyone with whom they come into contact, during the course of their activities, with respect, fairness and courtesy.

In doing his investigation, Poirot does not discriminate any gender nor race and nationality and he fulfills the code where private investigators should act with fairness and impartiality. I see his treatment of the all twelve passengers, although with different approaches, does not discriminate unlawfully on the grounds of race, sex, color and social origin. One of the clear example is when M. Bouc suspects the Italian passenger. 
"Without a doubt, that is the solution of the mystery. Doubtless he and this Ratchett were in this kidnapping business together. Cassetti is an Italian name. In some way Ratchett did on him what they call the double-cross. The Italian tracks him down, sends him warning letters first, and finally revenges himself upon him in a brutal way. It is all quite simple."

Poirot shook his head doubtfully.

"It is hardly so simple as that, I fear," he murmured. (p. 111-112)

When M. Bouc suspects the Italian due to the stereotype of Italian people during that time, Poirot stays neutral and sticks true to the data and facts collected from the passengers. He does not assume people's behavior based on nationality and race. In this context, I see that his justice stays true with his code of conduct as private investigators which are to act with fairness and impartiality.

In the end, when Poirot proposes his solutions, he also explains the bitter truth of Armstrong tragedy is based on the facts he has collected through his legal procedure. Since he is the only one to be the legal force in the situation, he has the right in delivering his solutions of the case.

"Now you all know the facts of the case. Mr. Ratchett was found stabbed this morning. He was last known to be alive at 12.37 last night when he spoke to the Wagon Lit conductor through the door. A watch in his pyjama pocket was found to be badly dented, and it had stopped at a quarter past one. Dr. Constantine, who examined the body when found, puts the time of death as having been between midnight and two in the morning. At half an hour after midnight, as you all know, the train ran into a snowdrift. After that time it was impossible for anyone to leave the train. (p. 258)

In this context, Poirot takes the role of a judge where he presents his evidence and his summary of the solutions. He asks his two friends as the jury of his solution. His treatment fulfills with the theory of procedural justice that a party of legal force determine the outcome of decision making through its legal procedure.

I find that Poirot understands there is a natural law which stands together with morality, one which demands the retribution from the murder of the innocent little Daisy. On the other hand, there is a written law which demands that those who do murder for the sake of vengeance or personal gain should be taken to the law because he or she is guilty. However, Poirot decides to side with morality. In this context, his view goes against the theory of retributive justice in which the punishment given to the offender should be done through the legal authority. In this context, he agrees with the view of the twelve passengers where the murder of Cassetti was an act to pay of his guilt despite it is an act of personal vengeance. Thus, I see that despite his strong objective in investigating the truth he still considers the moral reasons behind the murder and thus sees that morality precedes any form of written law, including retributive justice.

\section{Retributive Justice and Morality in Linda Arden's point of view}

Linda Arden plays the biggest role in bringing Cassetti to justice. She is a famous actress and grandmother to Daisy Armstrong. Not only does she have a strong personal relation to the Armstrong family, she also condemns the way Cassetti escapes the law. Among the eleven passengers, she has the strongest personal vengeance in killing Cassetti, and thus, her understanding of retributive justice comes from a personal reasoning. I see that the murder done by Linda Arden and the others, obviously, is an act of revenge. However, it is also an act of retribution. Retribution is "a view of crime as the sole responsibility of a morally flawed criminal offender who freely chooses the wrong course of action over the right. The primary cause of crime, for the retributivist, is the bad moral decisions of offenders" (Golash, 2005). In my opinion, this act is a way of making right what the offender has caused wrong without any personal gain. 
Since Ratchett himself does not want to right his wrongs, and he violates the courts procedure, Linda Arden and the other eleven decide to take the capital punishment in their own hand. They plan the murder so carefully that they do not want to involve another innocent in the process. Later on, I see that despite their subjective goals, their purpose is to prevent the possibility of future crimes.

"... the sentence of death that Cassetti had escaped had got to be carried out. There were twelve of us-or rather eleven; Susanne's father was over in France, of course. First we thought we'd draw lots as to who should do it, but in the end we decided on this way. It was the chauffeur, Antonio, who suggested it. Mary worked out all the details later with Hector MacQueen. He'd always adored Sonia-my daughter-and it was he who explained to us exactly how Cassetti's money had managed to get him off. (p. 272)

This shows how hurt the victims of Ratchett's hideous act and his punishmet should be carried out even outside the legal law. I think the victims also have the right to bring justice because they are the biggest party who suffer injustice. However, even though they have a just cause, the act itself is actually illegal because they do not have the legality of bringing the capital punishment; hence their act is considered as an act of vigilante.

Second interesting finding that I find in my analysis is that the act which Linda Arden has done alongside with the eleven passengers is a collective morality based on norm. It is generally accepted that the basic morality of human condones the act of killing another person, especially innocent children. Thus, in killing Cassetti, they know that it is against the basic moral of humanity. However, each of them feels a greater loss of an innocent child in the hand of immoral criminal that the law has failed to acknowledge; thus, Linda Arden alongside with the eleven passengers decide that normatively, the death of Cassetti must be done.

In doing the crime, they show the normative definition of morality, "among those who use "morality" normatively, virtually all hold that "morality" refers to a code of conduct that applies to all who can understand it and can govern their behavior by it, though many hold that it protects a larger group" Gert (2017). In this way, I see that Linda Arden and the others understand that the killing of Cassetti, despite being based on strong emotional reason, is needed to prevent the possibility of his heinous crime and to put the justice that the victims want for good.

Despite their noble deeds in killing criminal, I still see it as an act of wrongdoing and immoral. First, it is because they have no legal power to do so. Secondly, it is because they also agree on the notion of killing another human being which for me is against the basic knowledge of human virtue. In conclusion, through Linda Arden's point of view, an act of vigilante is also an act of delivering justice whereas the legal justice itself has failed to bring what ought to be served. She positions herself as an agent who brings out the punishment for the criminal outside the circle of legal authority.

\section{CONCLUSION}

This research in understanding justice from Murder on The Orient Express appear to promote a different idea about justice. The research is able to pinpoint some examples of the two main characters' interactions and find out their point of view of their understanding about justice.

I found that the retributive in their point of view is different than the theory. In Hercule Poirot, the process of procedural in doing investigation is needed, but the final verdict in reporting the murderers is not a must. This is because for him, there is another concept that goes beyond the legal procedure: morality. Poirot considers the reason of morality as another component in deciding a murder as just or not. In analyzing Linda Arden, I found that her point of view in 
retributive justice comes in a subjective reasoning. However, despite the subjective reason, she still considers the deterrent aspect for the criminal. In this way, I see that her action in killing Cassetti as an act of preventing more crimes. This analysis also gives me a new perspective of the justice in the story and further understanding of capital punishment regarding criminals and those who run free from the process of legal court.

In the analysis of using retributive justice and morality, I can pinpoint the characterization of the characters and how it shows their understanding of justice through their point of views. Furthermore, the finding of morality supports the motion on the discussion of capital punishment, which in conclusion can be considered as just.

I would recommend that using a psychological approach as the main theory in the future study to further expand the possibility of exploring the theme of the story, and creating a more critical analysis in the result. I also would recommend to explore the justice of twelve passengers instead of only three characters as it can give a deeper research, even though the result of the twelve passengers in the story would have the same objective in killing a criminal. I think that by exploring the psychology of twelve passengers, researchers will find the different reasons of their murder, and thus can create more diverse points.

\section{REFERENCES}

Agatha Christie biography. (2014). A\&E Television Networks. Retrieved July $2^{\text {nd }} 2019$ from: https://www.biography.com/writer/agatha-christie

Alschuler, Albert. (2003). The changing purposes of criminal punishment: A retrospective on the past century and some thoughts about the next. The University of Chicago Law Review. Retrieved December $18^{\text {th }}, 2018$ from: https://chicagounbound.uchicago.edu/cgi/viewcontent.cgi?referer=https://www.google.c om/\&httpsredir $=1 \&$ article $=1893 \&$ context=journal_articles

Bhandari, D.R. Plato. (n.d.). Plato's concept of justice: an analysis. J.N.V. University. Retrieved $17^{\text {th }}$ December 2018 from: https://www.bu.edu/wcp/Papers/Anci/AnciBhan.htm

Burke, Thomas Patrick. (2011) The concept of justice: is social justice just?. Continuum International Publishing Group.

Christie, Agatha. (1934). Murder on the orient express. Great Britain. Collins.

Code of conducts of private investigators. (n.d.) Retrieved May $3^{\text {rd }} 2019$ from: https://privateinvestigator-training.org.uk/code-of-conduct-for-private-investigators/

Gert, Bernard and Gert, Joshua. The definition of morality. The Stanford Encyclopedia of Philosophy. (Fall 2017 Edition). Edward N. Zalta (ed.). Retrieved 6 ${ }^{\text {th }}$ May 2019 from: https://plato.stanford.edu/entries/morality-definition/\#MoraLinkAdvoCode

Facts about murder on the orient express. (n.d.) Retrieved November $9^{\text {th }} 2018$ from: https://www.agathachristie.com/film-and-tv/murder-on-the-orient-express/facts-aboutmurder-on-the-orient-express

Fister, Barbara. (2014). The mystery of it all: why we enjoy crime fiction. Retrieved September $1^{\text {st }} 2018$ from: https://barbarafister.wordpress.com/2014/10/25/the-mystery-of-it-allwhy-we-enjoy-crime-fiction/

Kant, Immanuel. (1790). The science of right.

Maisse, Michelle. (2003). Types of justice. Retrieved $2^{\text {nd }}$ March 2019 from: https://www.beyondintractability.org/essay/types-of-justice

Masters, Kristin. (2014). A brief history of the mystery novel. Retrieved September $1^{\text {st }} 2018$ from: https://blog.bookstellyouwhy.com/a-brief-history-of-the-mystery-novel

McGuire, James. (2004). Understanding psychology and crime. England. Open University Press. 
Miller, David. (2017). Justice. The Stanford Encyclopedia of Philosophy. Retrieved April $28^{\text {th }}$ 2019 from: https://plato.stanford.edu/entries/justice/

Neale, Eleanor. (2018). The Junko Furuto case. Retrieved May $6^{\text {th }} 2019$ from: https://www.youtube.com/watch?v=Y45Bzcv57S0

Walen, Alec. (2016). "Retributive justice". The Stanford Encyclopedia of Philosophy. Edward N. Zalta (ed.). Retrieved December $18^{\text {th }} 2018$ from: https://plato.stanford.edu/archives/win2016/entries/justice-retributive/

Wilhelm, Jeffry D. (2001). Improving comprehension with think-aloud strategies. (p. 142). Retrieved $25^{\text {th }}$ August 2018 from:

http://teacher.scholastic.com/reading/bestpractices/comprehension/genrechart.pdf 